\title{
Mapping of Groundwater Potential Zones in Crystalline Terrain Using Remote Sensing, GIS Techniques, and Multicriteria Data Analysis (Case of the Ighrem Region, Western Anti-Atlas, Morocco)
}

\author{
Khalid Benjmel ${ }^{1, * \mathbb{D}}$, Fouad Amraoui ${ }^{1}$, Said Boutaleb ${ }^{2}$, Mohammed Ouchchen ${ }^{2}$, Amine Tahiri ${ }^{1}$ \\ and Amine Touab ${ }^{2}$ \\ 1 Laboratory of Geosciences Applied to Engineering Development (G.A.I.A), Faculty of Sciences Ain Chock, \\ Hassan II University, Casablanca 20150, Morocco; amraoui_f@hotmail.com (F.A.); \\ tahiri.amine28@gmail.com (A.T.) \\ 2 Laboratory of Applied Geology and Geo-Environment, Faculty of Science, Ibn Zohr University, Agadir \\ 80000, Morocco; saidboutaleb1@yahoo.fr (S.B.); ouchen.geol@gmail.com (M.O.); touab.am@gmail.com (A.T.) \\ * Correspondence: khalidbenjmelstu@gmail.com; Tel.: +212-678-114-886
}

Received: 24 December 2019; Accepted: 22 January 2020; Published: 10 February 2020

\begin{abstract}
This research work is intended as a contribution to the development of a multicriteria methodology, combining several factors to control the availability of groundwater resources, in order to optimize the choice of location of future drilling and increase the chances to take water from productive structures which will satisfy the ever-increasing water demand of local population (Arghen basin in the Western Anti-Atlas chain of Morocco). The geographic information system is used to develop thematic maps describing the geometry and the hydrodynamic functioning of the aquifer. In this study, 11 factors including geology, topography, and hydrology, influencing the distribution of water resources were used. Based on the Analytical Hierarchy Process (AHP) model, GIS, and remote sensing, the study mapped and classified areas according to their hydrogeological potential. The favorable potential sectors cover $17 \%$ of the total area of the basin. The medium potential sectors account for $64 \%$, while the unfavorable areas cover $18 \%$ of the basin area. The groundwater potential map of the study area has been validated by comparing with data from 159 boreholes scattered throughout the basin.
\end{abstract}

Keywords: Ighrem; Arghen basin; hydrogeology of fractured environments; GIS; remote sensing; multicriteria analysis

\section{Introduction}

Water is a natural resource essential for life and sometimes a determining factor for socio-economic development of a country. This is the case in Morocco where groundwater is characterized by scarcity, spatiotemporal irregularity, and vulnerability to anthropic effects. In such a context, it is imperative to identify groundwater resources and optimize the use in a rational manner. This research work is focused on a mountainous area with low water potential which is developed in a fractured environment. The study area is closely limited by the Arghen basin, which is part of the crystalline basement of Ighrem region (Western Anti-Atlas chain). This watershed is in a difficult hydrogeological context because of its semi-arid bioclimatic stage and the geological complexity of the terrain where the crystalline basement formations are the most dominant. In these environments, the complexity of groundwater management is increased when these regions face a data scarcity [1]. In addition, the groundwater resources can hardly meet the growing demand driven by the changing demographics of 
rural populations [2-4]. The aquifers that form in this type of context generally consist of crystalline rocks of plutonic and metamorphic origin (gneiss, schists, micaschists, etc.). These are hard rocks that expose relatively homogeneous mechanical behavior and overall hydraulic properties and are characterized mainly by fracture permeability [5]. Conventional research and prospection methods (hydrochemical, geophysical, etc.) often take a long time, require a lot of financial resources, and need qualified personnel [6-8]. In recent decades, several studies have shown that the analytical hierarchy process (AHP), based on geographical information systems (GIS) and spatial remote sensing, offers good functionality for mapping the groundwater recharge area [7-11].

The main objective of this study was to evaluate the ability of AHP and GIS techniques to map potential groundwater areas, to provide policy makers and managers with a guide map for hydrogeological research, to guide the implementation of future points of water, and consequently reduce the costs of hydrogeological investigation.

\section{Study Area}

The Arghen watershed, situated in the lower watershed of the Souss River in southwestern Morocco, covers an area of $1059 \mathrm{~km}^{2}$ with a surface elevation of between 300 and $2500 \mathrm{~m}$ (Figure 1). Water supply sources are mainly groundwater that is used for both irrigation and drinking water through dug boreholes and pumping wells. This region has an arid climate with an average annual rainfall of $181 \mathrm{~mm}$, and an irregular annual distribution (more than $70 \%$ of annual rainfall occurs from November to February). The average temperature varies between $44^{\circ} \mathrm{C}$ in summer and $3{ }^{\circ} \mathrm{C}$ in winter.

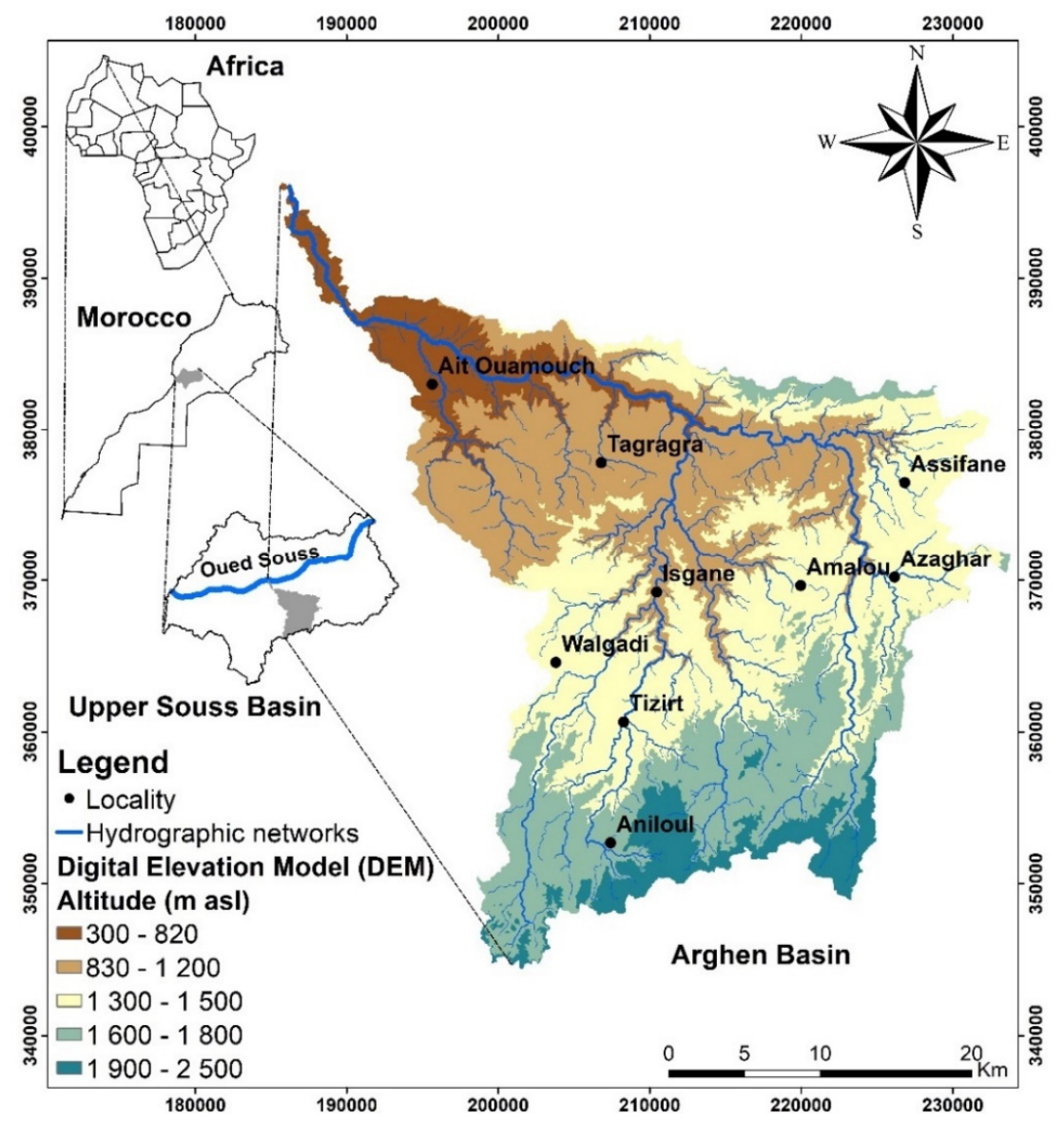

Figure 1. Geographic situation of Arghen basin. 
Geology

The study area is located in the contact zone between the Ighrem buttonhole formed by a Precambrian basement consisting largely of magmatic and metamorphic rocks [12], and a Paleozoic cover characterized by abundance of carbonate formations [13] (Figure 2). The Precambrian buttonhole of Ighrem consists of a Paleoproterozoic basement and a Neoproterozoic cover. The Paleoproterozoic formations of the study area outcrop in a dome with a subterranean cartographic orientation. These formations are bordered by the overlying Neoproterozoic formations. Most of the crystalline basement formations consist of granites and a metamorphic series represented by sandstone schists, micaschists, and gneisses, located in the immediate surroundings of the granites [12]. In the Ighrem buttonhole, the Neoproterozoic lies directly on the Paleoproterozoic. The contact between the two sets is often tectonic and shows the characters of the brittle-ductile transition. It is formed of two groups: The Ourty group has the base and that of Ighrem at the top. The Ourty group is represented by quartzites and limestones. It corresponds to the upper fragile unit, while Ighrem group refers to the conglomerates and volcano-detritic formations that have deposited in late to post Pan-African basins [12].

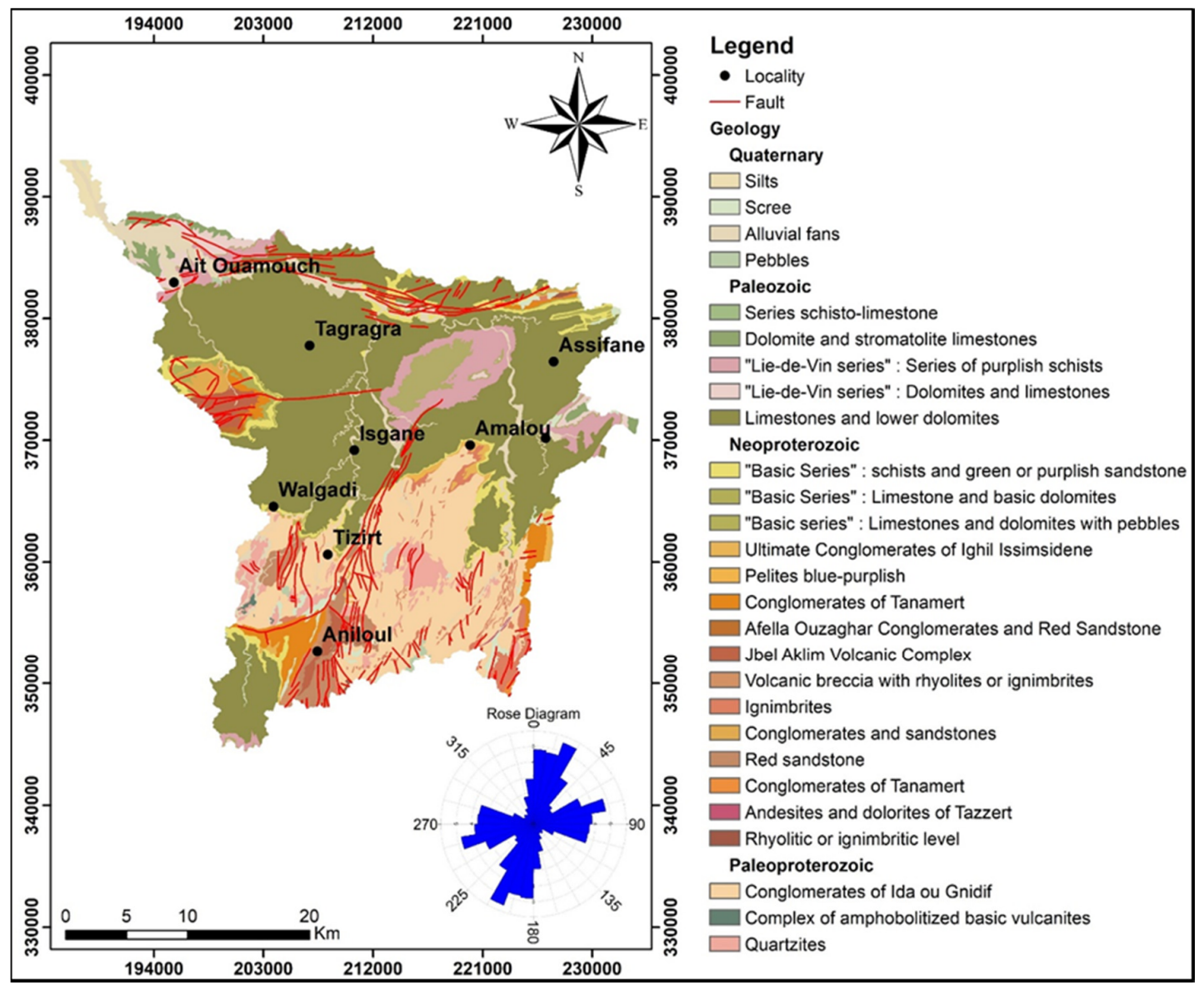

Figure 2. Geological map of Arghen basin.

The upper Neoproterozoic comprises poorly classified conglomeratic formations with striated pebbles of metamorphic quartzites. Evoking glacial formations, it lies either directly on the Paleoproterozoic basement, particularly in the region of Tanmiterte and d'lssourg, or directly on the quartzites of the Ourty group [14]. In the late Neoproterozoic, the Ighrem group consists of often rough detritic deposits and volcanic rocks (ignimbrites, pyroclastites of a rhyolitic, dacitic, or andesitic nature). The latter are surmounted by detrital facies which testify to a generalized emersion of the Western Anti-Atlas at the end of the Neoproterozoic [12]. 
After the continental deposits and the volcanic manifestations of the late Neoproterozoic, the Anti-Atlas domain is characterized by marine, carbonate, transgressive sedimentation coming from the west and the northwest forming the Paleozoic cover [13]. The lower Paleozoic is characterized by deposits of carbonate platform at the base, evolving towards more and more detrital terms upwards. The Upper Paleozoic is essentially detrital with carbonate intercalations of a more or less deep platform [15]. Deposits of regs, debris cones, and scree are the old, middle, and recent quaternaries. Alluvial deposits are alluviums of low silty terraces and modern alluvium. These sediments of various facies are present in small intra-mountain basins and along the rivers [15].

\section{Materials and Methods}

Numerical cartographic and statistical methods were applied in order to map areas with different groundwater potentiality. Therefore, this section consists of three main steps: (1) Construction of the geospatial database, (2) calculation of weights for groundwater prospecting factors, and (3) validation of the result. Geospatial data were developed in the Arc GIS 10.4.1 software, while weight generation for groundwater prospecting factors and associated functions were calculated by the AHP method in the Microsoft Excel software. The result of the validation are shown in a histogram that shows the rate of failure and success for having high flows in each class of underground potentiality obtained. The final output map was generated in Arc GIS 10.4.1 software using a raster calculator tool by multiplying each factor with its weight. The following flowchart (Figure 3) summarizes the different steps of this study.

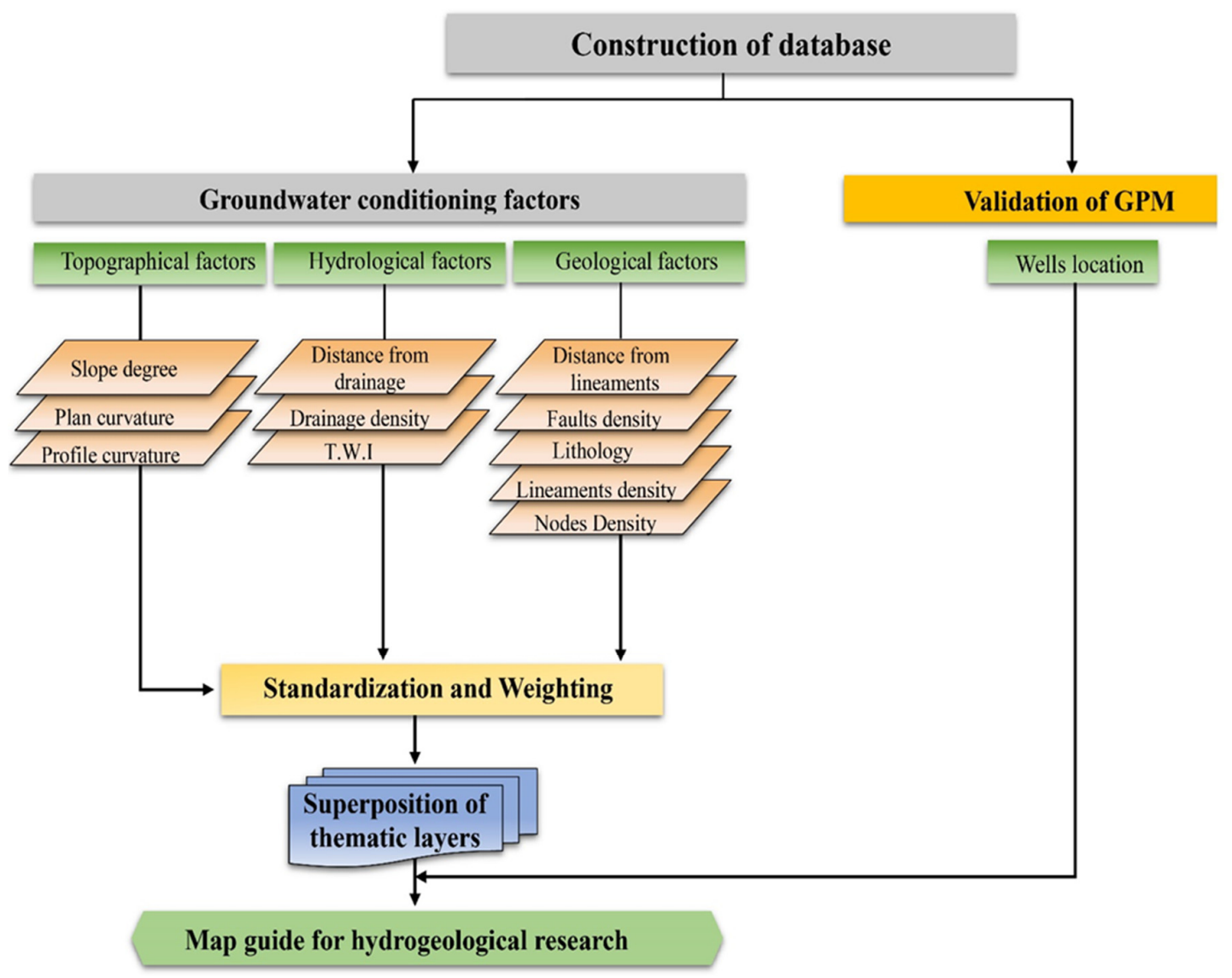

Figure 3. Flow chart of the methodology used in this study.

\subsection{Groundwater Influencing Factors}

Generally, the presence and productivity of groundwater in a given aquifer depends on a variety of factors, and, therefore, the number of conditioning factors used also depends on the availability of 
data in the study area [9]. In this study, 11 groundwater influencing factors were used. These factors were broadly divided into three types: Topographic, hydrological, and geological factors to ensure effective prediction of the groundwater potential of the study area within a GIS framework.

\subsubsection{Topographical Factors}

Topographical factors are presenting as the degree of slope, the plan curvature, and the profile curvature. Consideration of slopes is very important for favorable locations for water infiltration because low slope areas have low surface runoff and high percolation rates, while steep slopes favor runoff and fast evacuation of meteoric waters by drainage [16]. The slope map, generated on the digital elevation model (DEM) basis with a spatial resolution of $30 \mathrm{~m}$, shows that the areas of low slopes are located in the downstream part and along the river draining the watershed area of Arghen, while areas of strong slope were in the upstream part especially at the level of the crystalline basement (Figure 4a). In general, the southern regions are more exposed to groundwater recharge because runoff flows much more slowly than in the northern regions. The curvature represents the morphology of the topography and consists of three aspects: Profile, plan, and total, the latter combining profile and plan. Profile curvature (Figure $4 \mathrm{~b}$ ) and plan curvature (Figure $4 \mathrm{c}$ ) mainly affect flow acceleration and deceleration, as well as flow convergence and divergence, at the soil surface [17]. These factors were extracted from the DEM using an ArcGIS 10.4.1 software spatial analysis tool.

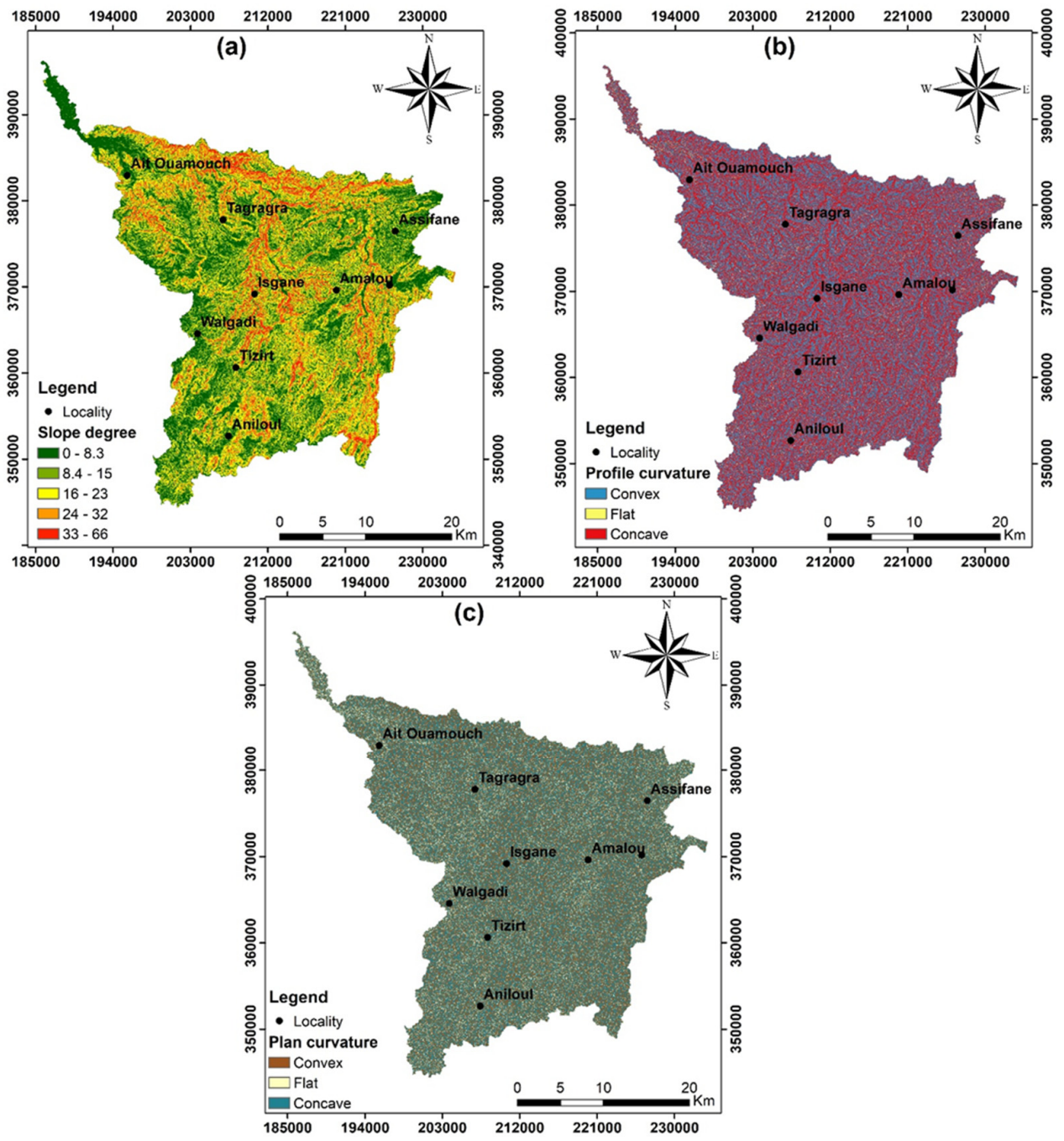

Figure 4. Topographical factors influencing groundwater. (a) Slope degree, (b) profile curvature, (c) plan curvature. 


\subsubsection{Hydrological Factors}

Hydrological factors, such as topographic wetness index (TWI), distance to the hydrographic network, and drainage density, were taken into consideration in the estimation of surface water and groundwater flow based on topographical factors. TWI is a secondary topographic index that has been used to describe spatial moisture patterns and to explain the effects of topographic conditions on these models [18]. It plays an important role in influencing the movement and accumulation of runoff at the soil surface (Figure 5a) [19]. TWI is calculated using the following equation:

$$
\mathrm{TWI}=(\mathrm{As} / \tan \beta)
$$

where As is the cumulative surface of the ascending slope and $\beta$ is the gradient of the slope.

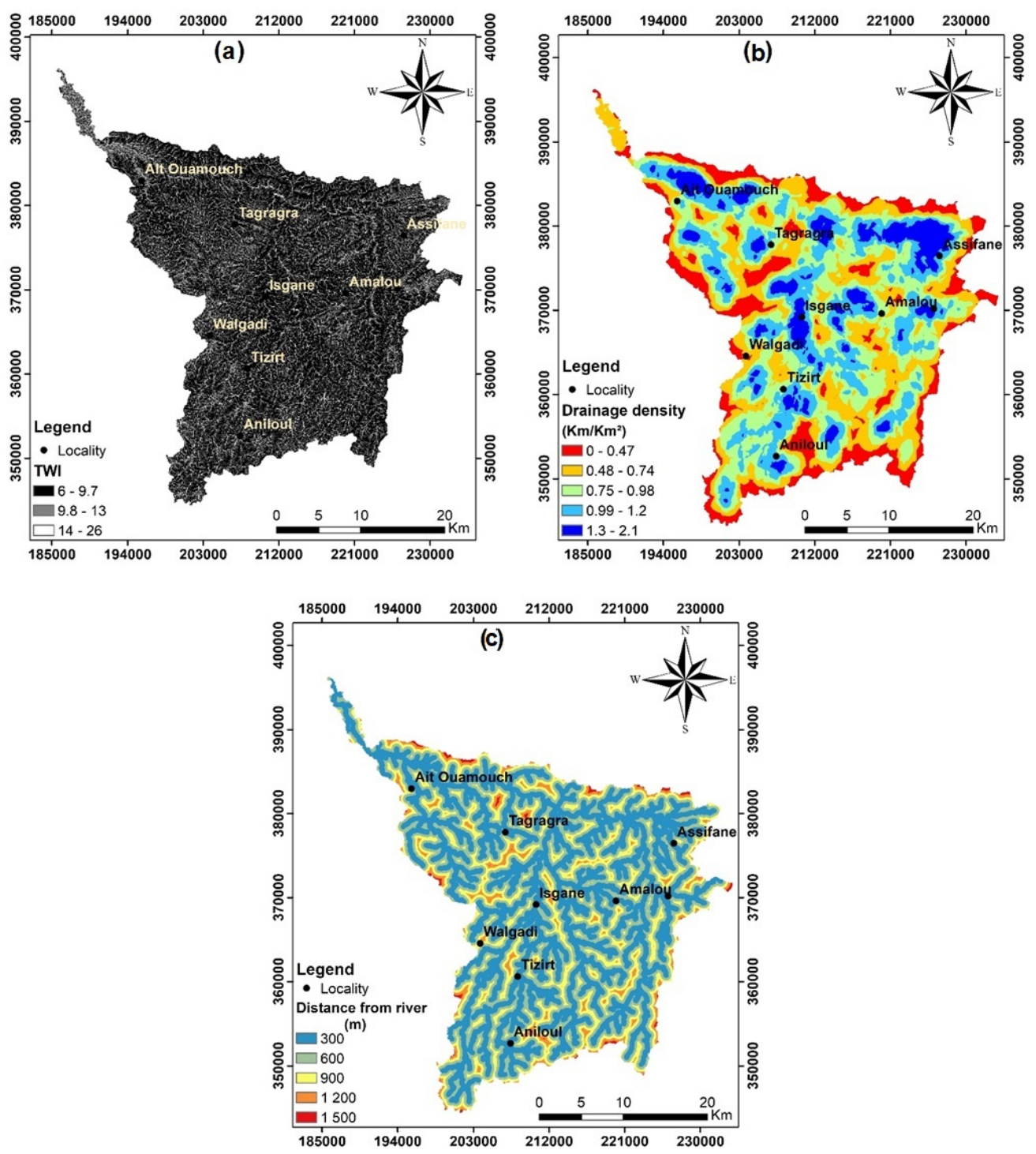

Figure 5. Hydrological factors influencing groundwater: (a) Topographic wetness index, (b) drainage density, (c) distance from river. 
The detailed study of the spatial hydrographic network density by mesh allows the detection of areas where infiltration occurs. It thus makes it possible to delimit aquifer recharge zones (Figure 5b). Hydrographic network density is calculated using the following equation:

$$
\mathrm{Dd}=\sum \mathrm{Li} / \mathrm{A}
$$

with $\mathrm{Dd}$ as the drainage density $\left(\mathrm{km}^{-1}\right), \sum \mathrm{Li}$ : the cumulative length of drains in each surface unit $(\mathrm{km})$, and A: the area $\left(\mathrm{km}^{2}\right)$.

In general, drainage density is inversely related to permeability. A high drainage density decreases infiltration and increases surface runoff and is, therefore, not suitable for groundwater development [20]. These high values are concentrated mainly in the Arghen, Ighil, and Berguene rivers. Several research studies have shown that the criterion of distance from hydrographic networks is important in hydrogeological research, because in semi-arid regions the existence of a local alluvial layer is mainly located near the rivers. It seems that areas close to the river $(300 \mathrm{~m})$ are promising for effective infiltration, hence, the existence of thick alluvial levels (very permeable formations), while beyond a distance greater than $600 \mathrm{~m}$ these resources will be difficult to find (Figure 5c). Drain density and distance from hydrographic networks were determined using the line density tool and the Euclidean distance tool in ArcGIS 10.4.1 software.

\subsubsection{Geological Factors}

Geological factors control the porosity and permeability of aquifer materials and are, therefore, considered as indicators of hydrological characteristics. The factors used in this study are: Lithology, geological fault density, lineament density, distance from lineaments, and nodes density. The geology of areas without a local aquifer is an important criterion as it can amplify or mitigate the extent of surface water percolation to aquifer rocks. The permeable formations favor the infiltration of water, through the underground flows. On the opposite, impermeable rocks, such as crystalline rocks, promote surface runoff.

The Arghen basin was divided into 27 units depending on the type of lithology. In this study, these units were classified according to their characteristics and permeabilities: Sedimentary rocks A, sedimentary rocks B, sedimentary rocks $C$, and igneous rocks. Sedimentary rocks A are highly permeable formations formed from silts, scree, and quaternary gravel, while sedimentary rocks $\mathrm{B}$ are moderately permeable formations consisting mainly of fractured limestones, dolomites, conglomerates, and fractured quartzites. On the other hand, type $C$ sedimentary rocks are formed by pelites with igneous rocks, and are impervious to surface water circulation (Figure 6a). 

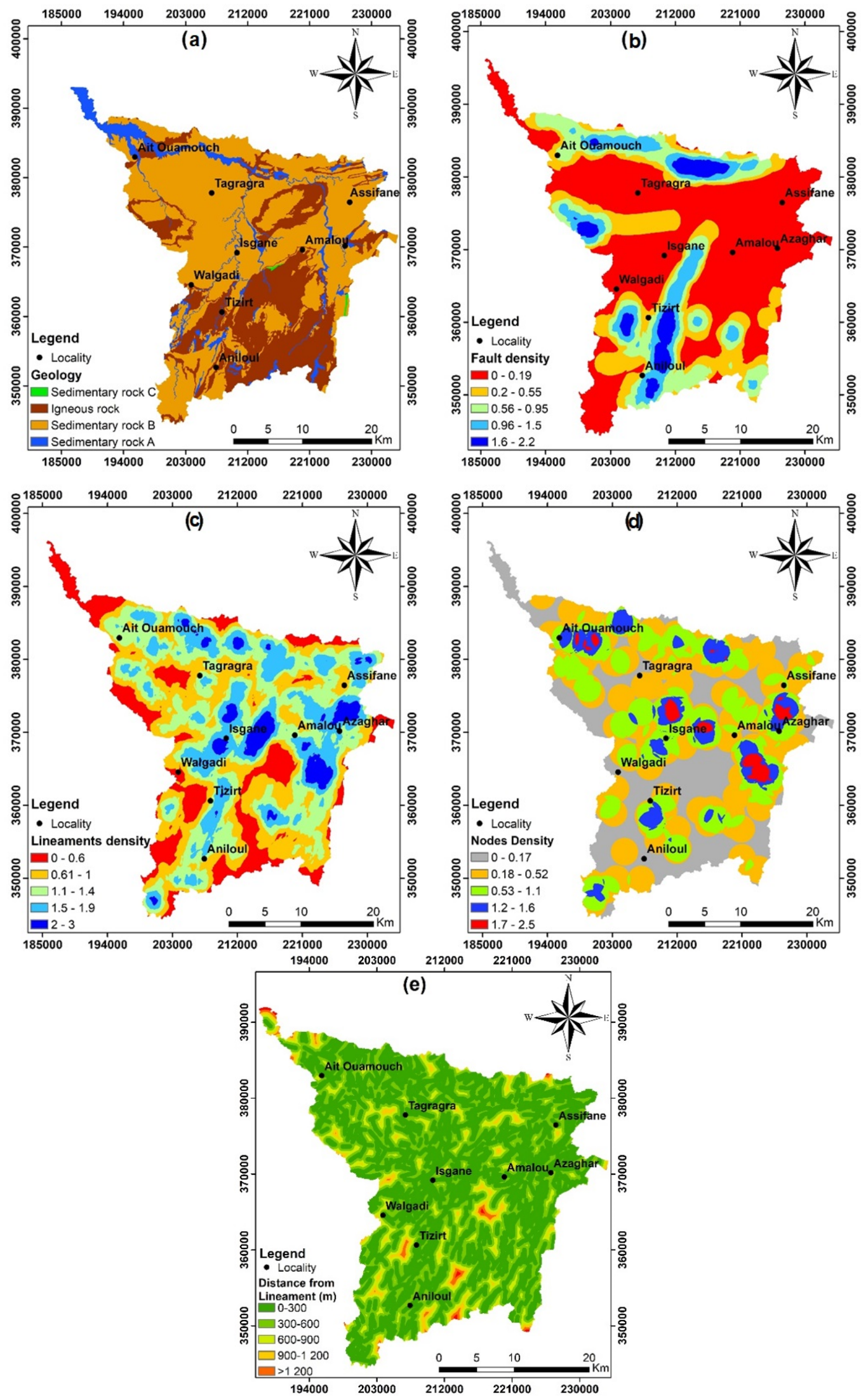

Figure 6. Geological factors influencing groundwater: (a) Lithology, (b) geological faults density, (c) lineaments density, (d) nodes density, (e) distance from lineaments. 
Lineaments are linear or curvilinear structures often associated with geomorphological features and/or various tectonic structures. These linear structures appear on the surface of the Earth as a form of discontinuities in the relief or in the ground cover. The rectilinearity of natural structures, such as geological structures (faults, fractures, lithological limits,) or drainage networks (rivers), reflects the influence of a phenomenon occurring below the surface of the ground. The detection of these structures facilitates a better characterization of existing reservoirs and the discovery of new aquifers linked to the existence of high density which favors the circulation of water towards the bottom. The lineaments of the study area were extracted from the Landsat 8 Oli satellite image. Extraction of these lineaments shows that the direction NE-SW (Northeast-Southwest) constitutes the major direction detected whose frequency is very high. This orientation is comparable to those found by the authors [12-14] on their structural geology study on the Ighrem sector. To validate the influence of this major direction (N40), we proceeded to the extraction of all the faults of the geological map of Ighrem and Taroudant with a scale of $1 / 100,000$, which covers the whole of the study area. The results are elaborated as a map of fracturing density which can be used to verify the reliability of our linear analysis. It confirms the actual dominance of this direction detected by the filter on the satellite image, but shows a second direction $\mathrm{EW}$, which is probably dominant in the sector $\mathrm{N}$ of the watershed (Figure $6 \mathrm{~b}$ ).

Orientation is not the only element characterizing a network of lineaments. Knowledge of its density and connectivity is also important [21]. The accuracy of the lineament mapping led to a higher density at two targets: The central part of the crystalline basement of Ighrem where the ground is strongly tectonized and the western part of the carbonate cover (Figure $6 \mathrm{c}$ ). In the same way, the density map of the nodes represents the number of intersections of lineaments per surface mesh. This parameter made it possible to highlight a density of lineaments. Generally, average to strong density is located at the central part of the buttonhole of Ighrem and at the western part of the carbonate cover. An area of significant importance can be detected in the contact zone between the Lie-de-Vin series and that of the carbonate cover (Figure $6 \mathrm{~d}$ ). The criterion of distance from lineaments is also important in hydrogeological research, since zones of hydrogeological interest must be located mainly in the vicinity of linear structures. In this study, areas closed to lineaments $(300 \mathrm{~m})$ were the most promising for effective infiltration, but the effect of this parameter decreased at distances greater than $700 \mathrm{~m}$ (Figure 6e).

\subsection{Analytical Hierarchy Process (AHP) Model}

The analytical hierarchy process (AHP) was introduced for the first time by [22]. This approach has four very important steps: (1) Standardization of the assessment criteria, (2) generation of a comparison matrix in pairs including all the thematic layers (weighting of the evaluation criteria), (3) verification of the incoherence of the elaborated matrix, and (4) aggregation of weighted decision criteria.

\subsection{Standardization of Thematic Layers by AHP Model}

The set of criteria used in this study was measured on different scales. For this reason, it needed to be standardized in a common interval which varied in our case from 2 to 10 (Table 1 ). The highest values thus express the greatest suitability for the most favorable sites for the implantation of water points. 
Table 1. Intervals of standardization of the evaluation criteria.

\begin{tabular}{|c|c|c|c|c|c|}
\hline Factor (Units) & Class & Rating & Factor (Units) & Class & Rating \\
\hline \multirow{6}{*}{$\begin{array}{l}\text { Slope degree } \\
(\%)\end{array}$} & $0-8.3$ & 10 & \multirow{5}{*}{ Nodes Density } & $0-0.17$ & 2 \\
\hline & $8.4-15$ & 8 & & $0.18-0.52$ & 4 \\
\hline & $16-23$ & 6 & & $0.53-1.1$ & 6 \\
\hline & $24-32$ & 4 & & $1.2-1.6$ & 8 \\
\hline & $33-66$ & 2 & & $1.7-2.5$ & 10 \\
\hline & $0-300$ & 10 & \multirow{5}{*}{$\begin{array}{l}\text { Distance from } \\
\text { lineaments }(\mathrm{m})\end{array}$} & $0-300$ & 10 \\
\hline \multirow{4}{*}{$\begin{array}{l}\text { Distance from } \\
\text { river }(\mathrm{m})\end{array}$} & $300-600$ & 8 & & $300-600$ & 8 \\
\hline & $600-900$ & 6 & & $600-900$ & 6 \\
\hline & $900-1200$ & 4 & & $900-1200$ & 4 \\
\hline & $1200-1500$ & 2 & & $>1200$ & 2 \\
\hline \multirow{2}{*}{ Lithology } & $\begin{array}{l}\text { High } \\
\text { permeability }\end{array}$ & 10 & \multirow[b]{2}{*}{ TWI } & $6-9.7$ & 2 \\
\hline & $\begin{array}{l}\text { Medium } \\
\text { permeability }\end{array}$ & 8 & & $9.8-13$ & 4 \\
\hline \multirow{6}{*}{$\begin{array}{c}\text { Lineaments } \\
\text { density }\end{array}$} & $\begin{array}{l}\text { Low } \\
\text { permeability }\end{array}$ & 6 & \multirow{6}{*}{$\begin{array}{c}\text { Profile } \\
\text { curvature }\end{array}$} & $14-26$ & 6 \\
\hline & $0-0.6$ & 2 & & $-6.5-(-0.01)$ & 2 \\
\hline & $\begin{array}{l}0.61-1 \\
11-14\end{array}$ & 4 & & $-0.009-0$ & 4 \\
\hline & $\begin{array}{l}1.1-1.4 \\
1.5-1.9\end{array}$ & $\begin{array}{l}6 \\
8\end{array}$ & & & \\
\hline & $\begin{array}{l}2-3.0 \\
2-3.9\end{array}$ & $\begin{array}{c}8 \\
10\end{array}$ & & $0.01-8.1$ & 6 \\
\hline & $0-0.47$ & 10 & & $-4.1-(-0.1)$ & 6 \\
\hline \multirow{4}{*}{$\begin{array}{c}\text { Drainage } \\
\text { density } \\
\left(\mathrm{km} / \mathrm{km}^{2}\right)\end{array}$} & $0.48-0.74$ & 8 & \multirow{3}{*}{ Plan curvature } & $-0.09-0$ & 4 \\
\hline & $0.75-0.98$ & 6 & & & \\
\hline & $0.99-1.2$ & 4 & & $0.01-4.9$ & 2 \\
\hline & $1.3-2.1$ & 2 & & & \\
\hline \multirow{5}{*}{ Faults density } & $0-0.19$ & 2 & & & \\
\hline & $0.2-0.55$ & 4 & & & \\
\hline & $0.56-0.95$ & 6 & & & \\
\hline & $0.96-1.5$ & 8 & & & \\
\hline & $1.6-2.2$ & 10 & & & \\
\hline
\end{tabular}

\subsection{Normalization of Weight for Thematic Layers by AHP Model}

In this research work, the weights of groundwater conditioning factors were determined from a pairwise comparison series taking into consideration the relative importance of two criteria to the ability to characterize potential groundwater locations. Their importance was determined on a four-level numerical scale, as shown in Table 2 and arranged in a decision matrix or pairwise comparison matrix (Tables 3 and 4 ).

Table 2. Verbal and numerical expression of the relative importance of a pair of criteria.

\begin{tabular}{lc}
\hline \multicolumn{1}{c}{ Importance } & Scale \\
\hline Equal importance & 1 \\
Weak & 2 \\
Moderate importance & 3 \\
Moderate plus & 4 \\
Less important & $1 / 2$ \\
Moderately less important & $1 / 3$ \\
Much less important & $1 / 4$ \\
\hline
\end{tabular}


Table 3. Pairwise comparison matrix of 11 groundwater prospecting factors for the analytical hierarchy process (AHP).

\begin{tabular}{|c|c|c|c|c|c|c|c|c|c|c|c|}
\hline Factors & Slope & $\begin{array}{c}\text { D. } \\
\text { Density }\end{array}$ & $\begin{array}{c}\mathrm{F} . \\
\text { Density }\end{array}$ & Lithology & TWI & $\begin{array}{c}\text { Plan } \\
\text { Curvature }\end{array}$ & $\begin{array}{l}\text { Profile } \\
\text { Curvature }\end{array}$ & $\begin{array}{l}\text { Distance } \\
\text { from } \\
\text { River }\end{array}$ & $\begin{array}{c}\text { L. } \\
\text { Density }\end{array}$ & $\begin{array}{c}\text { Distance } \\
\text { from } \\
\text { LINEAMENT }\end{array}$ & $\begin{array}{c}\text { N. } \\
\text { Density }\end{array}$ \\
\hline Slope & 1.00 & $1 / 2$ & $1 / 2$ & $1 / 2$ & 3.00 & 2.00 & 2.00 & $1 / 2$ & $1 / 3$ & $1 / 2$ & $1 / 2$ \\
\hline D. density & 2.00 & 1.00 & 2.00 & 3.00 & 4.00 & 3.00 & 3.00 & 3.00 & 1.00 & 2.00 & 2.00 \\
\hline F. density & 2.00 & $1 / 2$ & 1.00 & $1 / 3$ & 2.00 & 3.00 & 3.00 & 4.00 & 1.00 & $1 / 2$ & $1 / 3$ \\
\hline Lithology & 2.00 & $1 / 3$ & 3.00 & 1.00 & 3.00 & 2.00 & 2.00 & 2.00 & 3.00 & 2.00 & 1.00 \\
\hline TWI & $1 / 3$ & $1 / 2$ & $1 / 2$ & $1 / 3$ & 1.00 & 2.00 & 2.00 & $1 / 2$ & $1 / 3$ & $1 / 3$ & $1 / 4$ \\
\hline Plan curvature & $1 / 2$ & $1 / 3$ & $1 / 3$ & $1 / 2$ & $1 / 2$ & 1.00 & 1.00 & 2.00 & $1 / 3$ & 2.00 & $1 / 3$ \\
\hline $\begin{array}{l}\text { Profile } \\
\text { curvature }\end{array}$ & $1 / 2$ & $1 / 3$ & $1 / 3$ & $1 / 2$ & $1 / 2$ & 1.00 & 1.00 & 2.00 & $1 / 3$ & 2.00 & $1 / 3$ \\
\hline $\begin{array}{l}\text { Distance from } \\
\text { river }\end{array}$ & 2.00 & $1 / 3$ & $1 / 4$ & $1 / 2$ & 2.00 & $1 / 2$ & $1 / 2$ & 1.00 & $1 / 4$ & 1.00 & $1 / 2$ \\
\hline L. density & 3.00 & 1.00 & 1.00 & $1 / 3$ & 3.00 & 3.00 & 3.00 & 4.00 & 1.00 & $1 / 2$ & $1 / 2$ \\
\hline $\begin{array}{l}\text { Distance from } \\
\text { Lineament }\end{array}$ & 2.00 & $1 / 2$ & 2.00 & $1 / 2$ & 3.00 & $1 / 2$ & $1 / 2$ & 1.00 & 2.00 & 1.00 & $1 / 3$ \\
\hline N. Density & 2.00 & $1 / 2$ & 3.00 & 1.00 & 4.00 & 3.00 & 3.00 & 2.00 & 2.00 & 3.00 & 1.00 \\
\hline
\end{tabular}

Table 4. Determining the normalized weights for each thematic layer.

\begin{tabular}{|c|c|c|c|c|c|c|c|c|c|c|c|c|}
\hline Factors & Slope & $\begin{array}{c}\text { D. } \\
\text { Density }\end{array}$ & $\begin{array}{c}\text { F. } \\
\text { Density }\end{array}$ & Lithology & TWI & $\begin{array}{c}\text { Plan } \\
\text { Curvature }\end{array}$ & $\begin{array}{l}\text { PROFILE } \\
\text { Curvature }\end{array}$ & $\begin{array}{l}\text { Distance } \\
\text { from } \\
\text { River }\end{array}$ & $\begin{array}{c}\text { L. } \\
\text { Density }\end{array}$ & $\begin{array}{c}\text { Distance } \\
\text { from } \\
\text { Lineament }\end{array}$ & $\begin{array}{c}\text { N. } \\
\text { Density }\end{array}$ & Weight \\
\hline Slope & 0.06 & 0.05 & 0.04 & 0.07 & 0.12 & 0.09 & 0.09 & 0.02 & 0.03 & 0.03 & 0.10 & 0.64 \\
\hline D. density & 0.12 & 0.11 & 0.14 & 0.26 & 0.12 & 0.14 & 0.14 & 0.10 & 0.05 & 0.13 & 0.06 & 1.24 \\
\hline F. density & 0.12 & 0.05 & 0.07 & 0.04 & 0.08 & 0.14 & 0.14 & 0.19 & 0.10 & 0.03 & 0.06 & 0.93 \\
\hline Lithology & 0.12 & 0.05 & 0.22 & 0.13 & 0.12 & 0.09 & 0.09 & 0.10 & 0.20 & 0.13 & 0.19 & 1.31 \\
\hline TWI & 0.02 & 0.03 & 0.04 & 0.04 & 0.04 & 0.09 & 0.09 & 0.02 & 0.03 & 0.02 & 0.05 & 0.44 \\
\hline Plan curvature & 0.03 & 0.03 & 0.02 & 0.07 & 0.02 & 0.05 & 0.05 & 0.10 & 0.03 & 0.13 & 0.05 & 0.52 \\
\hline $\begin{array}{c}\text { Profile } \\
\text { curvature }\end{array}$ & 0.03 & 0.03 & 0.02 & 0.07 & 0.02 & 0.05 & 0.05 & 0.10 & 0.03 & 0.13 & 0.05 & 0.52 \\
\hline $\begin{array}{l}\text { Distance from } \\
\text { river }\end{array}$ & 0.12 & 0.05 & 0.02 & 0.07 & 0.08 & 0.02 & 0.02 & 0.05 & 0.02 & 0.07 & 0.10 & 0.56 \\
\hline L. density & 0.17 & 0.21 & 0.07 & 0.07 & 0.12 & 0.14 & 0.14 & 0.19 & 0.10 & 0.03 & 0.10 & 1.21 \\
\hline $\begin{array}{l}\text { Distance from } \\
\text { Lineament }\end{array}$ & 0.12 & 0.05 & 0.14 & 0.07 & 0.12 & 0.02 & 0.02 & 0.05 & 0.20 & 0.07 & 0.06 & 0.84 \\
\hline N. density & 0.12 & 0.32 & 0.22 & 0.13 & 0.16 & 0.18 & 0.18 & 0.10 & 0.20 & 0.20 & 0.19 & 1.81 \\
\hline
\end{tabular}

D. density, drainage density; L. density, lineaments density; F. density, faults density; N. density, nodes density.

To verify the consistency (CR) of the decision of the selected groundwater survey factors, the following formula was used. The following equation is used to calculate the CR:

$$
\mathrm{CR}=\mathrm{CI} / \mathrm{RI}
$$

where CI represents the consistency index calculated according to Equation (4) and RI is the random index of the constant consistency index of a sample of 500 randomly generated pairwise comparison matrices [23].

$$
\mathrm{CI}=(\lambda \max -n) /(n-1)
$$

where $\lambda \max$ is the largest eigen value of the matrix and can easily be determined from the matrix mentioned, and $\mathrm{n}$ is the number of groundwater conditioning factors, according to [22,24] as shown in Table 5. If the value of CR is less than or equal to 0.10, the matrix is acceptable [25]. If the consistency ratio is greater than 0.10 , it is necessary to revise the judgments to locate the cause of the inconsistency and correct it.

Table 5. Saaty's ratio index for different values of $n$.

\begin{tabular}{cccccccccccc}
\hline Order & $\mathbf{1}$ & $\mathbf{2}$ & $\mathbf{3}$ & $\mathbf{4}$ & $\mathbf{5}$ & $\mathbf{6}$ & $\mathbf{7}$ & $\mathbf{8}$ & $\mathbf{9}$ & $\mathbf{1 0}$ & $\mathbf{1 1}$ \\
\hline RI & 0.00 & 0.00 & 0.52 & 0.89 & 1.11 & 1.25 & 1.35 & 1.40 & 1.45 & 1.49 & 1.52 \\
\hline
\end{tabular}


The IC was calculated for: $\lambda \max =12,507, n=11$, and $R I=1.52$. Finally, the consistency ratio was calculated as $C R=0.09$ and is $<0.10$. This implies that there is a reasonable level of consistency in the pairwise comparison matrix.

\subsection{Definition of the GWPI}

Once the layers of the assessment criteria have been established and assigned to weighting coefficients, it remains only to combine these information plans by calculating the groundwater potential index (GWPI). This parameter represents a dimensionless quantity that predicts the potential zones of groundwater in an area. The weighted linear combination method was used to estimate the groundwater potential index [24-26]. GWPI was calculated using Equation (5) below:

GWPI $=0.64 \times$ Slope $+1.24 \times$ Drainage density $+0.93 \times$ Fault density $+1.31 \times$ Lithology

$+0.44 \times$ TWI $+0.52 \times$ Plan curvature $+0.52 \times$ Profile curvature $+0.56 \times$ Distance from river

$+1.21 \times$ Lineament density $+0.84 \times$ Distance from Lineament $+1.81 \times$ Nodes Density

\section{Results and Discussion}

\section{Mapping and Validation of Groundwater Potential Map}

The groundwater potential map was created by the combination of all the criteria developed on the basis of AHP techniques and the grid based on GIS. The GWPI values have been classified into three areas of groundwater potential: Nonpotential, moderate, excellent class. The most favorable zones represent $17.2 \%$ and, without taking into consideration the accessibility which sometimes becomes very difficult, the moderately favorable zones also represent $64.7 \%$. The rest is constituting $18.1 \%$, declared as unfavorable zones for hydrogeological research (Figure 7). According to Figure 7, the most suitable areas for the establishment of future drilling are located at the northern parts of the Arghen basin and in the central part of the crystalline basement of Ighrem because of their high density nodes, lineaments, and geological fractures. These parameters represent a first-order factor favoring efficient percolation of surface water towards the bottom. The concordance between the alignment of the boreholes and mapped lineages shows that these lineaments are fractures. This confirms that in the middle of the crystalline basement only the fractures are the real underground water corridors. These results are matching with the work of [27-30].

In order to validate a groundwater potential map, it is essential that the evaluation criterion chosen meets imperatively the concern for the reality of the ground, the principles of independence of the criterion, and its conformity [31]. For this purpose, verification of the groundwater potential map was generated using water point yield data from our study area. The flow rates of these water points were used to statistically show the rate of failure and success relative to each class of underground potential obtained (Figure 8). This analysis indicates the reliability of the method used. This is shown by the success rate of implanted drilling, which increased progressively towards the most productive areas $(51.64 \%)$. In parallel with this increase, there was another increase but this time the failure rate reached its maximum $(61.76 \%)$ in unfavorable areas for hydrogeological research. 


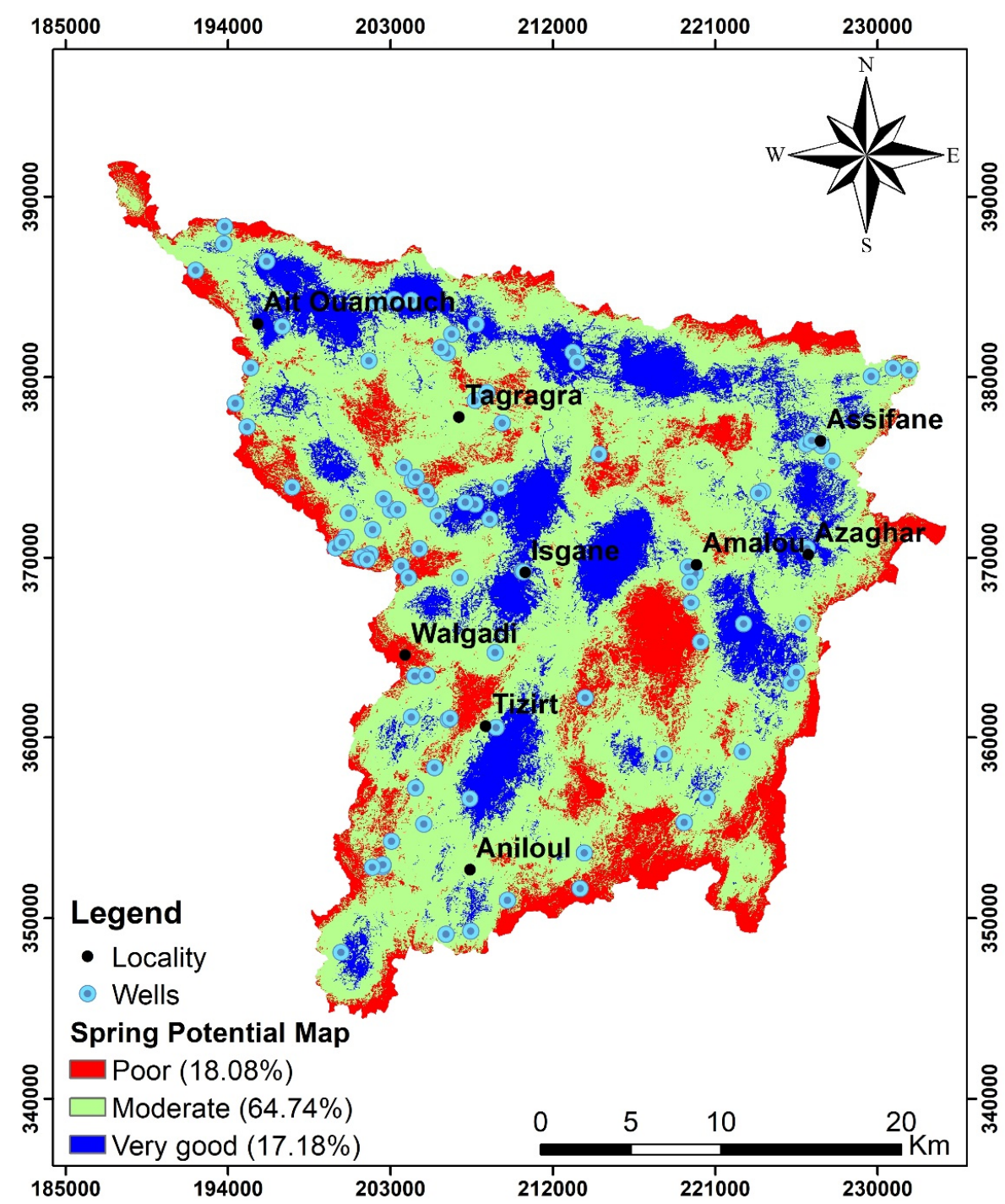

Figure 7. Groundwater potential map produced by AHP model.

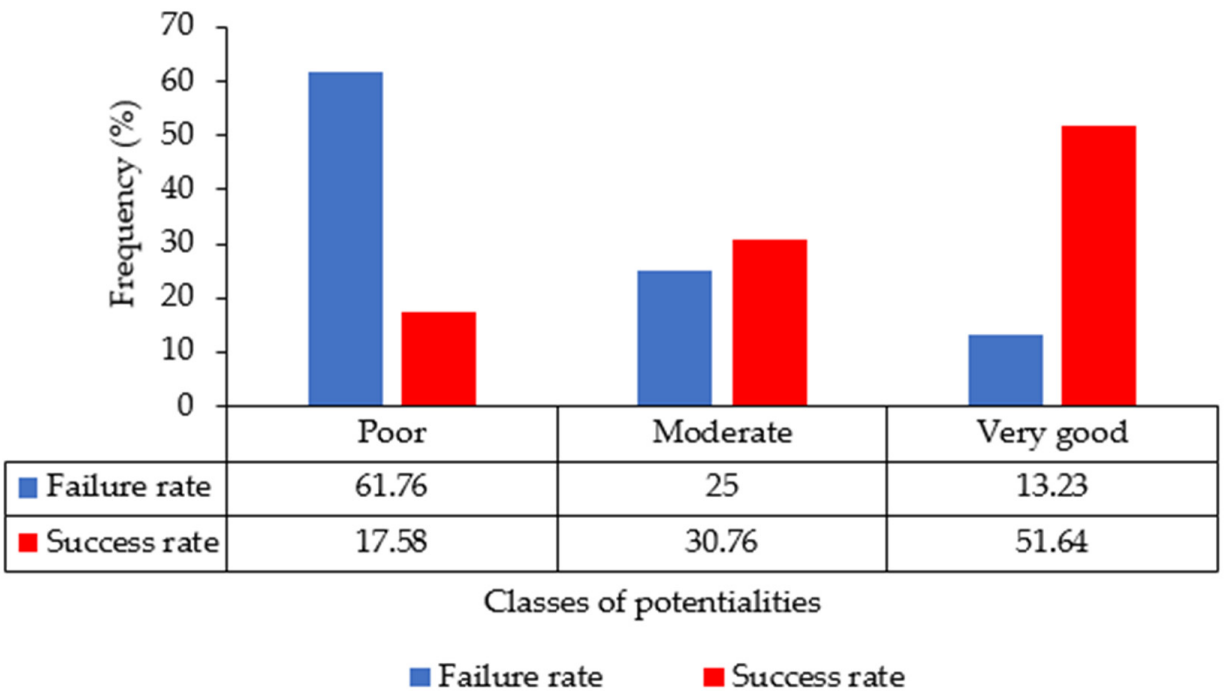

Figure 8. Trend histogram of failure and success rates for each potentiality class. 
The cartographic restitution of potential groundwater areas presented difficulties in its implementation. These came from the definition of the class limits of the chosen criteria of the method. For each criterion, the range of variation of the values was divided into a number of classes, according to chosen limit values, not necessarily equidistant but significant from the point of view of practical applications. The choice of class limits was based on the operator's ability to discern and the operator's sense of judgment. It can also depend on the values displayed by the histograms of the criteria [32], which were not fixed in our case. They depended on the presented values, the reality on the ground, and the objectives to be achieved. The mapping of parameters (fracturing density, drainage density, node density, etc.) by interpolation certainly led to errors. The interpolation was only reliable within the intervals delimited by the point data. It was also important to note that the cartographic support used was regional. Digital geological maps were only available on a scale of 1/100,000.

The establishment of the potential aquifer map using the Saaty weighting method did not better reflect the sensitivity of the terrain. In addition, this study suffered from the absence of drilling flows, especially in the northeast of Tizirt and in the east of Tagragra. The validation of the potential aquifer map should be improved by using data from recent drilling to better reproduce the realities on the ground. The identification of zones with a good potential aquifer did not guarantee a $100 \%$ success rate in drilling, even if the probability seemed high (51\%). In addition, the depth of investigation was also an element little mastered within the framework of the approach proposed in the study. All the analysis criteria used did not, in fact, dictate the hydrodynamic behavior in depth and were limited to hypothetical interpolations of surface data. The hydrodynamic functioning in the basement grounds was indeed more complex to ensure sustainability of the productivity of the structures. However, the most reliable way to validate the thematic potential aquifer map was to install new boreholes in each area, for which the thematic class indicated a given potential class, and check the productivity of these works. This, therefore, required having sufficient means. The choice of criteria used in this study was fairly compatible for arid and semi-arid climates where rainfall is quite low and the geology of the basin is highly tectonized and complex. On the other hand, in the most clement and humid regions, the proposed method would require further hydrological and climatological analysis to integrate related phenomena including precipitation, land use, and evapotranspiration in the process. In this case, the thematic map of areas with aquifer potential represented a decision-making tool which at least made it possible to exclude part of the territory to be prospected and to select sectors with promising aquifer potential. It was a strategic and tactical approach to limit investments in punctual prospecting towards the most suitable sites.

\section{Conclusions}

For a number of years, the Water Basin Agencies, responsible for planning, managing, and protecting water resources, have endeavored to find an adequate approach in order to develop a policy to identify the most favorable spots for the establishment of water points which will be used to supply the mainly rural population with drinking water. The present work responded to this demand by producing a series of spatial and temporal cartographic supports, based on a certain number of geological, topographic, and hydrological factors. All of these thematic maps were drawn in a GIS environment in order to identify areas with high aquifer potential. The potential aquifer map of the basement area of southwestern Morocco shows the areas likely to be subject to conventional prospecting with promise of success. The areas of the aquifer with good potential $(17.18 \%)$ were identified at the levels of the northern parts of the Arghen basin and in the central part of the crystalline basement of Ighrem. The areas with medium potential (64.74\%) were found in Aniloul, Tagragra, Amalou, and north of Assifane regions. Unfavorable areas (18.08\%) occupy approximately $1 / 5$ of the study area. The results indicate that the groundwater potential is mainly controlled by the density of nodes, lineaments, geological fracturing, and lithology. The validation of the results demonstrated that the AHP had good prediction precision if we consider that the flows released by the reconnaissance surveys are convincing. Therefore, on the basis of the results of this study, it can be concluded that 
this tool is presented as an orientation tool, capable of facilitating decisions and indicating research directions in terms of hydrogeological prospecting. The precise location of the boreholes and the determination of the most suitable operating flows should make the whole method converge towards a real decision-making aid tool in terms of water resources management and a function of orientation of master plans for the development, exploitation, and management of water resources.

To better appreciate the accuracy of the method and work to improve it, specific surveys are required in the safest and most productive areas. The logical path in such a fractured context would also require recourse to the exploration of aeromagnetic data in order to map geophysical lineaments in deep and major accidents of kilometer size, and to enhance the extraction of geological lineaments by the use of high-resolution radar images to cover larger prospecting areas.

Author Contributions: Conceptualization, F.A. and S.B.; methodology, K.B.; software, K.B. and M.O.; validation, K.B., A.T. (Amine Tahiri) and A.T. (Amine Touab); data curation, A.T. (Amine Touab); writing-original draft preparation, K.B.; writing-review and editing, K.B. and S.B. All authors have read and agreed to the published version of the manuscript.

Funding: This research received no external funding.

Conflicts of Interest: The authors declare no conflict of interest.

\section{References}

1. Bastani, M.; Kholghi, M.; Rakhshandehroo, G.R. Inverse modeling of variable-density groundwater flow in a semi-arid area in Iran using a genetic algorithm. Hydrogeol. J. 2010, 18, 1191-1203. [CrossRef]

2. Le Page, M.; Berjamy, B.; Fakir, Y.; Bourgin, F.; Jarlan, L.; Abourida, A.; Benrhanem, M.; Jacob, G.; Huber, M.; Sghrer, F. An integrated DSS for groundwater management based on remote sensing. The case of a semi-arid aquifer in Morocco. Water Resour. Manag. 2012, 26, 3209-3230. [CrossRef]

3. Mukherjee, P.; Singh, C.K.; Mukherjee, S. Delineation of groundwater potential zones in arid region of India-A remote sensing and GIS approach. Water Resour. Manag. 2012, 26, 2643-2672. [CrossRef]

4. Vaux, H. Groundwater under stress: The importance of management. Environ. Earth Sci. 2011, 62, 19-23. [CrossRef]

5. Boutaleb, S.; Boualoul, M.; Bouchaou, L.; Oudra, M. Application of Remote-Sensing and Surface Geophysics for Groundwater Prospecting in a Hard Rock Terrain, Morocco; Adelana, S.M.A., MacDonald, A.M., Eds.; IAH Book Series; IAH: Reading, UK, 2008; pp. 215-227.

6. Israil, M.; Al-Hadithi, M.; Singhal, D.C. Application of a resistivity survey and geographical information system (GIS) analysis for hydrogeological zoning of a piedmont area, Himalayan foothill region, India. Hydrogeol. J. 2006, 14, 753-759. [CrossRef]

7. Jha, M.K.; Chowdary, V.M.; Chowdhury, A. Groundwater assessment in Salboni Block, West Bengal (India) using remote sensing, geographical information system and multi-criteria decision analysis techniques. Hydrogeol. J. 2010, 18, 1713-1728. [CrossRef]

8. Todd, D.K.; Mays, L.W. Groundwater Hydrology; International Paperback; Wiley: Hoboken, NJ, USA, 2005.

9. Razandi, Y.; Pourghasemi, H.R.; Neisani, N.S.; Rahmati, O. Application of analytical hierarchy process, frequency ratio, and certainty factor models for groundwater potential mapping using GIS. Earth Sci. Inform. 2015, 8, 867-883. [CrossRef]

10. Madrucci, V.; Taioli, F.; de Araújo, C.C. Groundwater Favorability Map Using GIS Multicriteria Data; ELSEVIER: Amsterdam, The Netherlands, 2008.

11. Chenini, I.; Mammou, A.B.; El May, M. Groundwater recharge zone mapping using GIS-based multi-criteria analysis: A case study in Central Tunisia (Maknassy Basin). Water Resour. Manag. 2010, 24, 921-939. [CrossRef]

12. Oudra, M.; Beraaouz, H.; Ikenne, M.; Gasquet, D.; Soulaimani, A. La Tectonique Panafricaine du Secteur d'Igherm: Implication des dômes extensifs tardi à post-orogéniques (Anti-Atlas occidental, Maroc). Estudios Geológicos 2005, 61, 177-189. [CrossRef]

13. Boudda, A.; Choubert, G.; Faure-Muret, A. Essai De Stratigraphie De La Couverture Sédimentaire De L'Anti-Atlas: Adoudounien-Cambrien Inférieur Editions Du Service Géologique Du Maroc; Service Géologique: Rabat, Maroc, 1979. 
14. Oudra, M. La Structuration Panafricaine Dans La Partie Nord-Ouest De La Boutonnière D'Irhem (Anti-Atlas Occidental-Maroc); Université Cadi Ayyad: Marrakech, Maroc, 1988.

15. Benssaou, M.; Hamoumi, N. The western Anti-Atlas of Morocco: Sedimentological and palaeogeographical formation studies in the Early Cambrian. J. Afr. Earth Sci. 2001, 32, 351-372. [CrossRef]

16. Mogaji, K.A.; Lim, H.S.; Abdullah, K. Regional prediction of groundwater potential mapping in a multifaceted geology terrain using GIS-based Dempster-Shafer model. Arab. J. Geosci. 2015, 8, 3235-3258. [CrossRef]

17. Al-Abadi, A.M.; Al-Temmeme, A.A.; Al-Ghanimy, M.A. A GIS-based combining of frequency ratio and index of entropy approaches for mapping groundwater availability zones at Badra-Al Al-Gharbi-Teeb areas, Iraq. Sustain. Water Resour. Manag. 2016, 2, 265-283. [CrossRef]

18. Moore, I.D.; Grayson, R.B.; Ladson, A.R. Digital terrain modelling: A review of hydrological, geomorphological, and biological applications. Hydrol. Process. 1991, 5, 3-30. [CrossRef]

19. Elmahdy, S.I.; Mohamed, M.M. Probabilistic frequency ratio model for groundwater potential mapping in $\mathrm{Al}$ Jaww plain, UAE. Arab. J. Geosci. 2015, 8, 2405-2416. [CrossRef]

20. Dinesh Kumar, P.K.; Gopinath, G.; Seralathan, P. Application of remote sensing and GIS for the demarcation of groundwater potential zones of a river basin in Kerala, southwest coast of India. Int. J. Remote Sens. 2007, 28, 5583-5601. [CrossRef]

21. Gannouni, S.; Gabtni, H. Structural interpretation of lineaments by satellite image processing (Landsat TM) in the region of Zahret Medien (Northern Tunisia). J. Geogr. Inf. Syst. 2015, 7, 119. [CrossRef]

22. Saaty, T.L. The Analytic Hierarchy Process: Planning, Priority Setting, Resource Allocation; McGraw-Hill: New York, NY, USA, 1980.

23. Saaty, T.L. A scaling method for priorities in hierarchical structures. J. Math. Psychol. 1977, 15, $234-281$. [CrossRef]

24. Malczewski, J. GIS and Multicriteria Decision Analysis; John Wiley \& Sons: Hoboken, NJ, USA, 1999.

25. Saaty, T.L. Decision Making for Leaders: The Analytic Hierarchy Process for Decisions in a Complex World; RWS Publications; RWS: Pittsburgh, PA, USA, 1990.

26. Shekhar, S.; Pandey, A.C. Delineation of groundwater potential zone in hard rock terrain of India using remote sensing, geographical information system (GIS) and analytic hierarchy process (AHP) techniques. Geocarto Int. 2015, 30, 402-421. [CrossRef]

27. Algaydi, B.A.M.; Subyani, A.M.; Hamza, M.H.M.M. Investigation of Groundwater Potential Zones in Hard Rock Terrain, Wadi Na'man, Saudi Arabia. Groundwater 2019, 57, 940-950. [CrossRef]

28. Adeyeye, O.A.; Ikpokonte, E.A.; Arabi, S.A. GIS-based groundwater potential mapping within Dengi area, North Central Nigeria. Egypt. J. Remote Sens. Space Sci. 2019, 22, 175-181. [CrossRef]

29. Das, S. Delineation of groundwater potential zone in hard rock terrain in Gangajalghati block, Bankura district, India using remote sensing and GIS techniques. Model. Earth Syst. Environ. 2017. [CrossRef]

30. Lasm, T.; Kouame, F.; Oga, M.S.; Jourda, J.R.P.; Soro, N.; Kouadio, B.H. Étude De La Productivité Des Réservoirs Fracturés Des Zones De Socle Cas Du Noyau Archéen De Man-Danané(Ouest De La Côte d'Ivoire); Revue Ivoirienne des Sciences et Technologie: Abidjan, Côte d'Ivoire, 2004.

31. Morjani, E.; Abidine, Z.E. Conception D'un Système D'information À Référence Spatiale Pour La Gestion Environnementale: Application À La Sélection De Sites Potentiels De Stockage De Déchets Ménagers Et Industriels En Région Semi-Aride (Souss, Maroc); University of Geneva: Geneva, Switzerland, 2002.

32. Jourda, J.P.; Saley, M.B.; Djagoua, É.V.; Kouamé, K.J.; Biémi, J.; Razack, M. Utilisation Des Données ETM+ De Landsat Et D'un SIG Pour L'évaluation Du Potentiel En Eau Souterraine Dans Le Milieu Fissuré Précambrien De La Région De Korhogo (Nord De La Côte d'Ivoire); Contemporary Publishing International: Paris, France, 2006.

(C) 2020 by the authors. Licensee MDPI, Basel, Switzerland. This article is an open access article distributed under the terms and conditions of the Creative Commons Attribution (CC BY) license (http://creativecommons.org/licenses/by/4.0/). 